\title{
AN INTERFERENCE PHENOMENON BETWEEN VIRULENT AND AVIRULENT TUBERCLE BACILLI CONCERNING THEIR MULTIPLICATION AND SURVIVAL IN GUINEA PIGS, WITH SPECIAL REFERENCE TO THE MECHANISM OF VIRULENCE-ENHANCEMENT OF MYCOBACTERIAL STRAINS BY ANIMAL PASSAGE
}

\author{
KOOMI KANAI, SHIGERU KATSUYAMA AND KeN YANAGISAWA \\ Department of Tuberculosis, National Institute of Health, Tokyo
}

(Received: February 18th, 1955)

\section{INTRODUCTION}

The term "virulence" is generally used to represent the capacity of microorganisms to cause disease. This capacity is, however, determined by a number of different and independent factors in both sides of microorganisms and host. Therefore, if we hold the most inclusive view for the definition of virulence, we are compelled to use the expression "host-parasite relationship" as suggested by $\operatorname{Dubos}^{1)}$.

As for tubercle bacilli, it has been often shown by several investigators ${ }^{2)}$ 3) 4) 5) that their virulence is manifested in the degree of multiplication and survival in susceptible animals. In our previous report6), the difference in virulence between BCG and H37Rv was also demonstrated in this point.

In experimental studies on bacterial infection and immunity, the virulence of microorganisms is one of the most influential factors to control the outcome of the experiments. In this connection, it is quite necessary to know the virulence of the bacterial strains kept in our laboratory in any time of their use. It has been frequently stated ${ }^{7}{ }^{8}$, however, that some species of microorganisms decrease their virulence when subcultured on artificial media. On the other hand, it is also a common sense in bacteriology ${ }^{7}$ ) that repeated passage of a given strain of microorganisms through particular animals often results in enhancement of virulence of the strain. Hadley and Wetzel ${ }^{9)}$ have evidently shown this fact in the mice infection experiment using hemolytic streptococci. Our daily experience in experimental tuberculosis show that the same is likewise true in the case of tubercle bacilli.

The virulence-enhancement phenomenon by animal passage has been most readily explained as the result of the selection of the cells which are best adapted to multiplication in a given host. Experimental basis for this explanation, however, has been scarcely reported hitherto, probably due to technical difficulties. So, the present authors conducted a few experiments in an attempt to clarify the mechanism of the virulence-enhancement of tubercle bacilli by animal passage. 


\section{MATERIALS AND METHODS}

The principle of the virulence test and the estimation of antimycobacterial immunity were made pursuing the multiplication and survival of tubercle bacilli injected intravenously into guinea pigs, by the quantitative bacterial cultivation of weighed amount of organs. The bacteriological techniques employed were described in the previous report ${ }^{6)}$.

The bacterial strains employed were as follows.

H37Rv: Supplied by the Mayo Foundation.

H37Ra: Supplied by the Trudeau Laboratory.

H37RvR-SM: Supplied by the Mayo Foundation.

H37RaR-SM: Isolated in this laboratory from H37Ra in one step isolation method on Ogawa medium containing streptomycin in $100 \mathrm{\gamma} / \mathrm{ml}$.

BCGR-SM: Isolated in the same way as above from BCG which had been kept in this laboratory.

No. 386: Isolated from the sputum of a tuberculous patient in this laboratory. 386R-INH: Isolated from the above strain in one step on Ogawa medium containing isoniazid in $100 \gamma / \mathrm{ml}$.

As the experimental animals, healthy guinea pigs weighing 350 to $450 \mathrm{~g}$ were used.

\section{EXPERIMENTAL}

Experiment 1. Relation between virulence and immunogeneity in tubercle bacilli: Seventy-four normal guinea pigs were divided into eleven groups; four of them consisting of eight animals and remaining seven groups of six. The

Table 1. The outline of experiments concerning the relation between virulence and immunogenety in tubercle bacilli

\begin{tabular}{|c|c|c|c|c|c|c|c|c|c|c|c|c|}
\hline \multirow{2}{*}{$\begin{array}{c}\text { Experi- } \\
\text { mental } \\
\text { object }\end{array}$} & \multirow{2}{*}{ 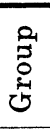 } & \multirow{2}{*}{$\underset{\text { No. }}{\text { Animal }}$} & \multicolumn{2}{|c|}{$\begin{array}{l}\text { Primary } \\
\text { infection }\end{array}$} & \multicolumn{8}{|c|}{ Experimental } \\
\hline & & & Strain & $\begin{array}{l}\text { Dose } \\
(\mathrm{mg})\end{array}$ & $1 \mathrm{~d}$. & $1 \mathrm{w}$. & $2 \mathrm{w}$. & $3 \mathrm{w}$. & $4 \mathrm{w}$. & $6 \mathrm{w}$. & $8 \mathrm{w}$ & $10 \mathrm{w}$. \\
\hline \multirow{4}{*}{$\begin{array}{c}\text { Virulence } \\
\text { test }\end{array}$} & A & $1-8$ & $\mathrm{H} 37 \mathrm{Rv}$ & 0.01 & $\mathrm{~B}, \mathrm{~B}$ & $\mathrm{~B}, \mathrm{~B}$ & $\mathrm{~A}, \mathrm{~A}$ & $\mathrm{~A}, \mathrm{~A}$ & $\mathrm{~A}, \mathrm{~A}$ & \multirow{4}{*}{$\begin{array}{l}\mathrm{A}, \mathrm{A} \\
\mathrm{A}, \mathrm{A}\end{array}$} & & \\
\hline & B & $9-16$ & H37Ra & 0.01 & $\mathrm{~B}, \mathrm{~B}$ & $\mathrm{~B}, \mathrm{~B}$ & $\mathrm{~A}, \mathrm{~A}$ & $\mathrm{~A}, \mathrm{~A}$ & $\mathrm{~A}, \mathrm{~A}$ & & & \\
\hline & $\mathrm{C}$ & $17-24$ & No. 376 & 0.01 & $\mathrm{~B}, \mathrm{~B}$ & $\mathrm{~B}, \mathrm{~B}$ & $\mathrm{~A}, \mathrm{~A}$ & $\mathrm{~A}, \mathrm{~A}$ & $\mathrm{~A}, \mathrm{~A}$ & & & \\
\hline & $\mathrm{D}$ & $25-32$ & 386R-INH & 0.01 & $\mathrm{~B}, \mathrm{~B}$ & $\mathrm{~B}, \mathrm{~B}$ & $\mathrm{~A}, \mathrm{~A}$ & A,A & $\mathrm{A}, \mathrm{A}$ & & & \\
\hline \multirow{7}{*}{$\begin{array}{l}\text { Immuno- } \\
\text { geneity } \\
\text { test }\end{array}$} & 1 & $33-38$ & $\mathrm{H} 37 \mathrm{Rv}$ & 0.01 & \multirow{7}{*}{\multicolumn{3}{|c|}{$\begin{array}{c}\text { period of } \\
\text { immunization }\end{array}$}} & \multirow{7}{*}{ 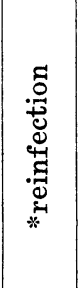 } & \multirow{4}{*}{ B } & B, B & $\mathrm{A}, \mathrm{A}$ & $\mathrm{A}, \mathrm{A}$ \\
\hline & 2 & $39-44$ & H37Ra & 0.01 & & & & & & B, B & $\mathrm{A}, \mathrm{A}$ & $\mathrm{A}, \mathrm{A}$ \\
\hline & 3 & $45-50$ & H.37Ra & 1.0 & & & & & & B, B & $\mathrm{A}, \mathrm{A}$ & $\mathrm{A}, \mathrm{A}$ \\
\hline & 4 & $51-56$ & No. 386 & 0.01 & & & & & & $\mathrm{~B}, \mathrm{~B}$ & $\mathrm{~A}, \mathrm{~A}$ & $\mathrm{~A}, \mathrm{~A}$ \\
\hline & 5 & $57-62$ & 386R-INH & 0.01 & & & & & \multirow[t]{2}{*}{ B } & $\mathrm{B}, \mathrm{B}$ & $\mathrm{A}, \mathrm{A}$ & $\mathrm{A}, \mathrm{A}$ \\
\hline & 6 & $63-68$ & 386R-INH & 1.0 & & & & & & B, B & $\mathrm{A}, \mathrm{A}$ & $\mathrm{A}, \mathrm{A}$ \\
\hline & 7 & $69-74$ & control & & & & & & B & B, B & $\mathrm{A}, \mathrm{A}$ & $\mathrm{A}, \mathrm{A}$ \\
\hline
\end{tabular}

Note: *Reinfection was made with $0.001 \mathrm{mg}$ of H37RvR-SM.

B...Biopsy, A...Autopsy 
former four groups were used for the virulence test of four strains of tubercle bacilli and the latter groups for the examination of their immunogeneity. The experimental design was shown being summarized in Table 1 . The strain undergone the tests were H37Rv, H37Ra, No. 386 and 386R-INH. For the observation of the comparative virulence of these strains, they were injected intravenously into guinea pigs in the amount of $0.01 \mathrm{mg}$, and after that, in one day, and then weekly for four weeks the quantitative bacterial cultivation to recover the injected bacilli was made of the spleens removed by biopsy or autopsy, each time using two animals of each group. The results were presented graphically in Fig. 1. The immunogeneity test was conducted by the reinfection experiment with $0.001 \mathrm{mg}$ of H37RvR-SM, which injected intravenously into guinea pigs immunized three weeks before by the intravenous injection with 0.01 or $1.0 \mathrm{mg}$ of the strains presented for the virulence test. Thereafter, the H37RvR-SM bacilli were recovered on streptomycin-containing Ogawa media differentially from the bacilli used for the immunization. The results were summarized in Table 2. In Fig. 1, it is shown that these four strains were different in virulence which was higher

Fig. 1. Growth curves of various strains of tubercle bacilli in guinea pigs

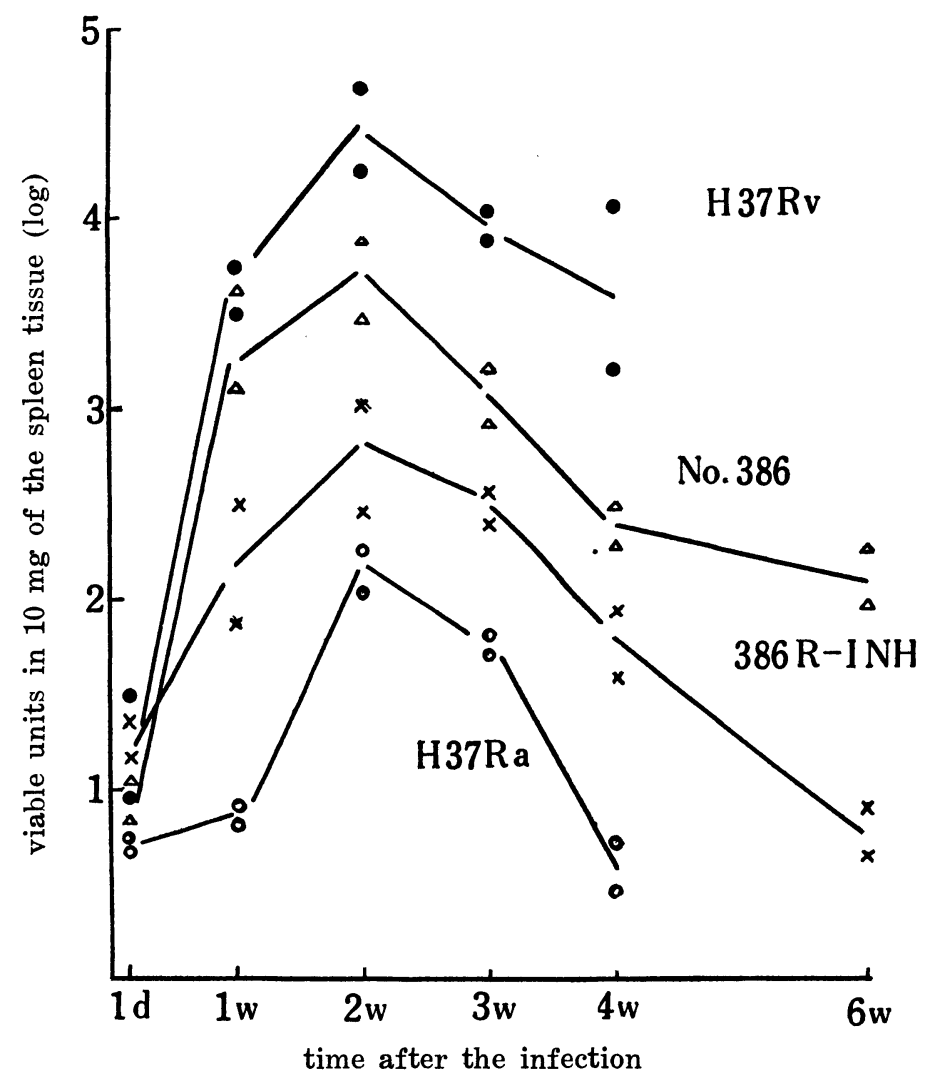


Table 2. Immunogeneity of various strains of tubercle bacilli in guinea pigs

\begin{tabular}{|c|c|c|c|c|c|}
\hline \multirow{3}{*}{$\begin{array}{l}\text { Strains used } \\
\text { for } \\
\text { immunization }\end{array}$} & \multicolumn{5}{|c|}{ Fate of secondly introduced tubercle bacilli* } \\
\hline & $1 \mathrm{~d}$. & $2 \mathrm{w}$. & $4 \mathrm{w}$. & \multicolumn{2}{|c|}{$6 \mathrm{w}}$. \\
\hline & \multicolumn{4}{|c|}{ Spleen } & Lung \\
\hline $\begin{array}{l}\mathrm{H} 37 \mathrm{Rv} \\
0.01 \mathrm{mg}\end{array}$ & & $\begin{array}{l}0 \\
0\end{array}$ & $\begin{array}{l}1 \\
0\end{array}$ & $\begin{array}{l}1 \\
0\end{array}$ & $\begin{array}{l}17 \\
11\end{array}$ \\
\hline $\begin{array}{l}\mathrm{H} 37 \mathrm{Ra} \\
0.01 \mathrm{mg}\end{array}$ & 6 & $\begin{array}{l}120 \\
540\end{array}$ & $\begin{array}{l}380 \\
730\end{array}$ & $\begin{array}{r}500 \\
1,500\end{array}$ & $\begin{array}{r}6 \\
60\end{array}$ \\
\hline $\begin{array}{l}\mathrm{H} 37 \mathrm{Ra} \\
1.0 \mathrm{mg}\end{array}$ & & $\begin{array}{l}45 \\
50\end{array}$ & $\begin{array}{r}16 \\
580\end{array}$ & $\begin{array}{l}170 \\
310\end{array}$ & $\begin{array}{l}10 \\
70\end{array}$ \\
\hline $\begin{array}{l}\text { No. } 386 \\
0.01 \mathrm{mg}\end{array}$ & & $\begin{array}{l}0 \\
0\end{array}$ & $\begin{array}{r}3 \\
11\end{array}$ & $\begin{array}{r}60 \\
9\end{array}$ & $\begin{array}{r}10 \\
0\end{array}$ \\
\hline $\begin{array}{l}386 \mathrm{R}-\mathrm{INH} \\
0.01 \mathrm{mg}\end{array}$ & 4 & 5 & $\begin{array}{r}30 \\
130\end{array}$ & $\begin{array}{l}380 \\
180\end{array}$ & $\begin{array}{l}6 \\
0\end{array}$ \\
\hline $\begin{array}{l}386 \mathrm{R}-\mathrm{INH} \\
1.0 \mathrm{mg}\end{array}$ & & $\begin{array}{l}0 \\
0\end{array}$ & $\begin{array}{l}0 \\
0\end{array}$ & $\begin{array}{l}1 \\
0\end{array}$ & $\begin{array}{l}0 \\
0\end{array}$ \\
\hline $\begin{array}{l}\text { Control } \\
\text { Non-immunized }\end{array}$ & 4 & $\begin{array}{r}650 \\
1,800\end{array}$ & $\begin{array}{l}1,800 \\
1,300\end{array}$ & $\begin{array}{l}1,100 \\
2,300\end{array}$ & $\begin{array}{r}1,300 \\
950\end{array}$ \\
\hline
\end{tabular}

in the order of H37Rv, No. 386, 386R-INH and H37Ra. Of particular interest, however, was the fact that in two weeks after the infection all these strains multiplied ten to thousand times in the number of viable units according to their respective virulence. And then, they took the tendency to decrease or survive. Concerning the virulence of isoniazid-resistant tubercle bacilli, special attentions have been paid by several investigators 10) 11) 12) 13) and the present authors will report our own detailed experiments in another papers. In this experiment, it was demonstrated that $386 \mathrm{R}-\mathrm{INH}$ was less virulent than the parent No. 386 strain, but more virulent than H37Ra strain. Both 386R-INH and H37Ra were, however, the same in their fate to have disappeared almost completely from guinea pigs in four or six weeks. Now, let us observe Table 2. First of all, we learn, in comparison with the control group, that the groups immunized previously showed the antibacterial immunity to inhibit the multiplication of the secondly introduced tubercle bacilli, although the intensity of the immunity were varied depending upon the strains and their dose used. The animals immunized with H37Rv or No. 386 showed a remarkable resistance to the secondary infection, but thuse immunized with H37Ra or 386R-INH were less active in inhibiting the growth of the secondly introduced tubercle bacilli. And further attentions must be paid to the difference of the immune power between the animals immunized with H37Ra and those with 386R-INH. Broadly speaking, the simultaneous consideration of Fig. 1 with Table 2 will indicate that the more virulent are the bacilli, the more intensely the immunity is produced in the hosts infected with them. 
Experiment 2. Comparative studies on the fate of avirulent tubercle bacilli in guinea pigs when injected intravenously with or without H37Rv: Setting aside the consideration concerning the association of tuberculin allergy and the formation of special lesions, the fate of tubercle bacilli in experimental animals appears to be determined by the balance between the virulence (the capacity to multiply) of the bacilli and the immunity produced in response to their multiplication. The reason why attenuated tubercle bacilli are poor in the ability to multiply in susceptible animals may be that the immunity produced against them is intense enough to overcome their virulence. In this connection, it will be easily supposed that the fate of avirulent or attenuated tubercle bacilli in susceptible animals will be modified in the concomitant presence of virulent tubercle bacilli. Therefore, two experiments were undertaken as follows in an attempt to make clear this matter and consequently to contribute something to the understanding of the virulence-enhancement phenomenon of tubercle bacilli by animal passage. The first experiment was conducted as follows. Six groups of normal guinea pigs were arranged, each consisting of seven.

Group A: Injected intravenously with $1 \mathrm{mg}$ of H37Rv.

Group B: Injected intravenously with $0.001 \mathrm{mg}$ of $\mathrm{H} 37 \mathrm{Rv}$.

Group C: Injected intravenously with $1 \mathrm{mg}$ of BCGR-SM.

Group D: Injected intravenously with $1 \mathrm{mg}$ of H37Rv and $1 \mathrm{mg}$ of BCGRSM.

Group E: Injected intravenously with $0.001 \mathrm{mg}$ of $\mathrm{H} 37 \mathrm{Rv}$ and $1 \mathrm{mg}$ of $\mathrm{BC}-$ GR-SM.

Group F: Injected intravenously with $0.5 \mathrm{mg}$ of $\mathrm{H} 37 \mathrm{Rv}$ and $0.5 \mathrm{mg}$ of BCGR-SM.

The initial experimental design had been that in one day, two, four, and six weeks after the infection, the numbers of viable units would be pursued in the spleen removed by biopsy of autopsy, each time using two animals in each group. The animals infected densely with virulent tubercle bacilli, however, began to die in about three weeks after the gradual decrease of body weight. So, in reality, the experiment was performed as shown in Table 3. The results were presented in Tables 4 and 5. These tables indicated that attenuated tubercle bacilli BCG injected intravenously in such a large amount as $1 \mathrm{mg}$ decreased in the number of viable units in the spleen within a relatively short period of time, but this tendency was further accelerated by the simultaneous injection with virulent tubercle bacilli. The present authors should like to explain this phenomenon as follows; if guinea pigs are injected with both virulent and attenuated tubercle bacilli, the intense immunity will be produced in the host principally by the stimulation due to the marked proliferation of the former bacilli, but the bacilli attacked most effectively by this immune power will not be the virulent bacilli themselves but the attenuated bacilli. On the other hand, the fate of virulent tubercle bacilli did not appear to have received any particular 
Table 3. The outline of the mixed infection experiment with virulent and attenuated tubercle bacilli in guinea pigs (I)

\begin{tabular}{|c|c|c|c|c|c|c|c|}
\hline \multirow{3}{*}{$\frac{\text { Group }}{\text { A }}$} & \multirow{2}{*}{\multicolumn{2}{|c|}{$\begin{array}{l}\text { Microorganisms } \\
\text { used for } \\
\text { infection (mg) }\end{array}$}} & \multicolumn{5}{|c|}{ Experimental } \\
\hline & & & \multirow{2}{*}{$\frac{1 \mathrm{~d} .}{\mathrm{B}, \mathrm{B}}$} & \multirow{2}{*}{$\frac{2 \mathrm{w} .}{\mathrm{A}, \mathrm{A}}$} & \multirow{2}{*}{$\begin{array}{l}\text { about } 3 \mathrm{w} . \\
\mathrm{D}, \mathrm{D}, \mathrm{D}, \mathrm{D}\end{array}$} & \multirow{2}{*}{$4 \mathrm{w}}$. & \multirow{2}{*}{$6 \mathrm{w}}$. \\
\hline & H37Rv & 1.0 & & & & & \\
\hline B & $\mathrm{H} 37 \mathrm{Rv}$ & 0.001 & $\mathrm{~B}, \mathrm{~B}$ & $\mathrm{~A}, \mathrm{~A}$ & & $\mathrm{~A}, \mathrm{~A}$ & $\mathrm{~A}, \mathrm{~A}$ \\
\hline C & RCGR-SM & 1.0 & $\mathrm{~B}, \mathrm{~B}$ & $\mathrm{~A}, \mathrm{~A}$ & $\mathrm{~A}, \mathrm{~A}$ & $\mathrm{~A}, \mathrm{~A}$ & A \\
\hline D & $\begin{array}{l}\text { H37Rv } \\
\text { BCGR-SM }\end{array}$ & $\begin{array}{l}1.0 \\
1.0\end{array}$ & $\mathrm{~B}, \mathrm{~B}$ & $\mathrm{~A}, \mathrm{~A}$ & $\mathrm{D}, \mathrm{D}, \mathrm{D}$ & & \\
\hline $\mathbf{E}$ & $\begin{array}{l}\text { H37Rv } \\
\text { BCGR-SM }\end{array}$ & $\begin{array}{l}0.001 \\
1.0\end{array}$ & $\mathrm{~B}, \mathrm{~B}$ & $\mathrm{~A}, \mathrm{~A}$ & & $\mathrm{~A}, \mathrm{~A}$ & $\mathrm{~A}, \mathrm{~A}$ \\
\hline F & $\begin{array}{l}\text { H37Rv } \\
\text { BCGR-SM }\end{array}$ & $\begin{array}{l}0.5 \\
0.5\end{array}$ & $\mathrm{~B}, \mathrm{~B}$ & $\mathrm{~A}, \mathrm{~A}$ & $\mathrm{D}, \mathrm{D}, \mathrm{D}$ & & \\
\hline
\end{tabular}

Note: B ... biopsy, A ... autopsy, D ... died

Table 4. The fate of H37Rv in guinea pigs when injected intravenousiy with or without BCGR-SM

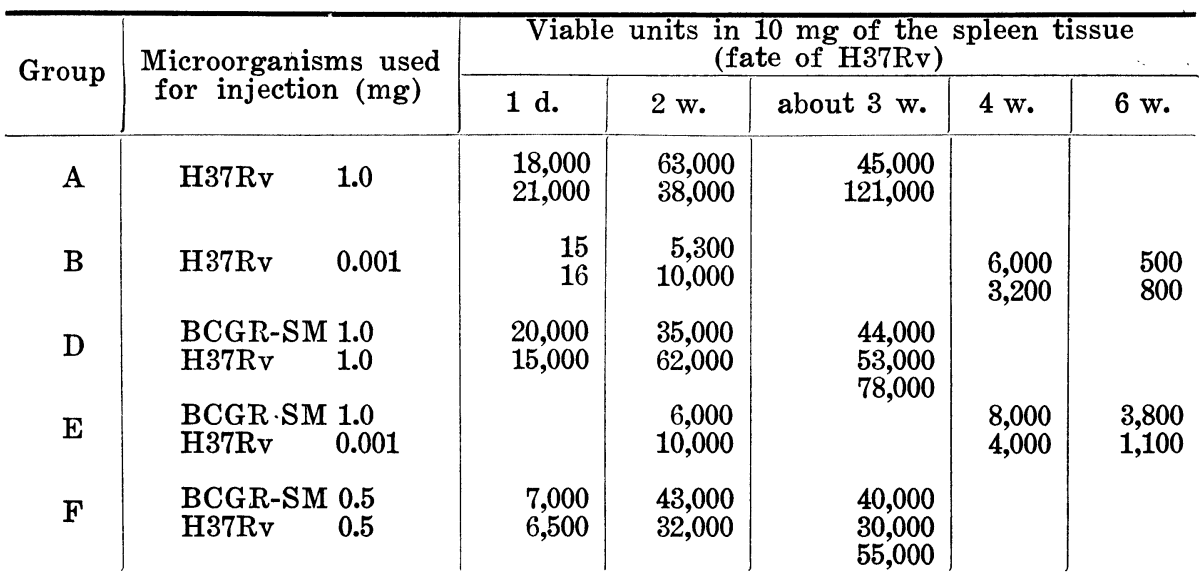

Table 5. The fate of BCGR-SM in guinea pigs when injected intravenously with or without H37Rv

\begin{tabular}{|c|c|c|c|c|c|c|}
\hline \multirow{2}{*}{ Group } & \multirow{2}{*}{$\begin{array}{l}\text { Microorganisms } \\
\text { used for infection } \\
\text { (mg) }\end{array}$} & \multicolumn{5}{|c|}{$\begin{array}{l}\text { Viable units in } 10 \mathrm{mg} \text { of the spleen tissue } \\
\text { (fate of BCGR-SM) }\end{array}$} \\
\hline & & $1 \mathrm{~d}$. & $2 \mathrm{w}$. & about 3 w. & $4 \mathrm{w}$ & $6 \mathrm{w}$. \\
\hline C & BCGR-SM 1.0 & $\begin{array}{r}7,000 \\
17,000\end{array}$ & $\begin{array}{l}2,300 \\
3,600\end{array}$ & $\begin{array}{r}60 \\
130\end{array}$ & $\begin{array}{r}90 \\
8\end{array}$ & 5 \\
\hline D & $\begin{array}{ll}\text { BCGR-SM } & 1.0 \\
\text { H37Rv } & 1.0\end{array}$ & $\begin{array}{r}6,000 \\
10,000\end{array}$ & $\begin{array}{l}60 \\
90\end{array}$ & $\begin{array}{l}0 \\
0 \\
0\end{array}$ & & \\
\hline $\mathbf{E}$ & $\begin{array}{ll}\text { BCGR-SM } & 1.0 \\
\text { H37Rv } & 0.001\end{array}$ & $\begin{array}{l}5,000 \\
4,000\end{array}$ & $\begin{array}{l}280 \\
160\end{array}$ & & $\begin{array}{l}0 \\
0\end{array}$ & $\begin{array}{l}0 \\
0\end{array}$ \\
\hline $\mathrm{F}$ & $\begin{array}{ll}\text { BCGR-SM } & 0.5 \\
\text { H37Rv } & 0.5\end{array}$ & $\begin{array}{r}3,000 \\
19,000\end{array}$ & $\begin{array}{l}50 \\
60\end{array}$ & $\begin{array}{l}0 \\
0 \\
0\end{array}$ & & \\
\hline
\end{tabular}


influence by the concomitant presence of the attenuated bacilli, probably due to the experimental condition of the massive intravenous infection. Then, the similar experiment was further conducted in order to confirm the findings described above. The experimental design was as follows. Four groups of guinea pigs were arranged, each consisting of seven.

Group I: Injected intravenously with $0.001 \mathrm{mg}$ of $\mathrm{H} 37 \mathrm{Rv}$ (23,000 viable units) and $0.1 \mathrm{mg}$ of H37RaR-SM (500,000 v. u.).

Group II: Injected intravenously with $0.1 \mathrm{mg}$ of H37RaR-SM (500,000 v. u.).

Group III: Injected intravenously with $0.001 \mathrm{mg}$ of No. 386 (6,800 v. u.) and $0.1 \mathrm{mg}$ of $386 \mathrm{R}-\mathrm{INH}$ (140,000 v. u.).

Group IV: Injected intravenously with $0.1 \mathrm{mg}$ of $386 \mathrm{R}-\mathrm{INH}(140,000 \mathrm{v}$. u.). The fate of H37RaR-SM and 386R-INH was pursued in the spleen and lung by the differential bacterial cultivation of the weighed amount of the tissue, using Ogawa media containing streptomycin or isoniazid in the concentration of 100 $\gamma / \mathrm{ml}$. The results were demonstrated in Fig. 2 and Fig. 3. What has been experienced in the previous experiment was again demonstrated in the fate of H37RaR-SM strain in the spleen and lung of guinea pigs as shown in Fig. 2, but the situation was different in the case of $386 \mathrm{R}-\mathrm{INH}$ and the result was unexpected, without showing any particular modification of its fate when injected

Fig. 2. The fate of H37RaR-SM in guinea pigs when injected intravenously with or without H37Rv

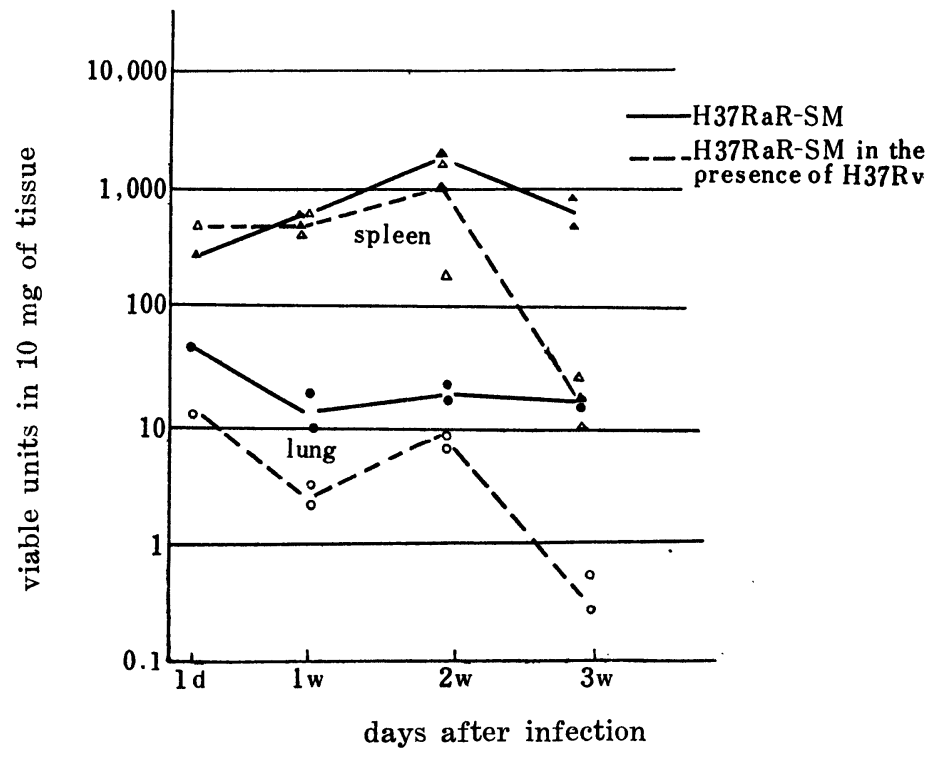


Fig. 3. The fate of $386 \mathrm{R}-\mathrm{INH}$ in guinea pigs when injected intravenously with or without No. 386

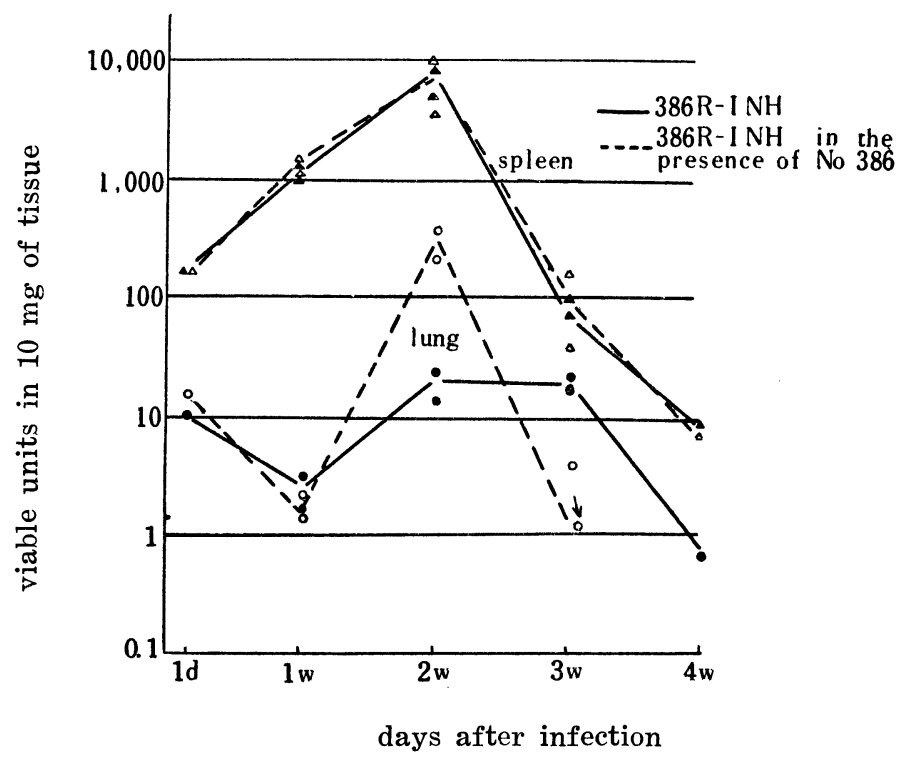

with No. 386. This may be explained, however, from the fact previously demonstrated that 386R-INH strain was high in virulence than H37Ra, although lower than the parent No. 386 strain. On the contrary, the growth of No. 386 was found to be considerably inhibited by the immunity produced in the earlier stadium of the infection by a large dose of $386 \mathrm{R}-\mathrm{INH}$, although not presented to the figures.

\section{Discussion}

According to the authors' opinion, the long-held view in bacteriology that tubercle bacilli increase their virulence after animal passage can be explained from the fact observed in the present study. That is to say, the bacilli of low-virulence disappeared more rapidly from the spleen and lung of guinea pigs when they were introduced to them with a minute amount of the bacilli of high virulence. The discussion will be continued to explain this point in more detail. First of all, it seems most important for the understanding of this problem that the virulent tubercle bacilli H37Rv could produce an intense immunity but the avirulent bacilli H37Ra did not so. Then, it will be very probable that the avirulent bacilli are destroyed more rapidly than the virulent bacilli by the antibacterial immunity specific to tubercle bacilli. Therefore, if the bacilli of the H37Ra strain are introduced into guinea pigs with those of the H37Rv strain, only the latter bacilli will multiply to a considerable extent, but the resulted 
immunity by them will act against the H37Ra bacilli with a more marked effects than against the H37Rv bacilli themselves. On the contrary, in the case of single injection of the H37Ra bacilli, the antibacterial immunity which competes with them will be produced only very weakly by these avirulent bacilli. In this way, the survival of the avirulent bacilli can be kept in a more prolonged period than that in the case of the combined injection with the H37Rv bacilli.

Now, let us think again about the meaning of bacterial virulence. In the introduction, the authors stated that the virulence of tubercle bacilli can be manifested in their capacity to multiply and survive in the bodies of susceptible animal. In addition to this, it appears also necessary for the proper understanding of virulence or pathogenicity of tubercle bacilli to consider the chemical constituents of bacillary bodies responsible for the production of pathological changes in those animals. However vigorously the bacilli may multiply, there will occur little harm in animals, if the bacilli are something like simple foreign body having no substance active chemically or physiologically against the host. In this connection, Saenz ${ }^{14}$ considered the virulence of tubercle bacilli as being composed of two factors, the multiplying capacity and the specific constituents of bacillary bodies. For instance, the killed or attenuated tubercle bacilli which essentially have no capacity to cause macroscopical lesions in guinea pigs could produce considerably large tubercles, if they were injected with the bacilli suspended in paraffin oil. Choucroun ${ }^{15)}$, Bloch ${ }^{16)}$ and Tsumita ${ }^{17)}$ have also demonstrated that toxic substances can be isolated from the bacillary bodies of BCG as well as from virulent tubercle bacilli. In other species of bacteria, it has been also shown ${ }^{18)}$ that typhoid or dysentery bacilli are not different in the point of toxin production from many other gram-negative bacteria, and among Group A streptococci none can produce a more powerful erythrogenic toxin than the N.Y. 5 type 12 strain which essentially avirulent for experimental animals.

The most important problem at present, however, is that the stock culture of tubercle bacilli which is usually used in our laboratory is considered to be a bacterial population in which the cells of high virulence, avirulence and intermediate virulence are mixed together. To make the matter more complicated, there are some evidences to indicate that the virulent bacilli lose their virulence spontaneously in the course of subcultures and that the proportion of the cells of varied virulence is always changing. In this case, the loss of virulence may be due to the variation of unknown factors responsible for in vivo multiplication, not to the variation of the chemical constituents responsible for the lesion production. In order to analyse this heterogenicity of virulence in a bacterial population, the examination of many single cells picked up one by one by the micromanipulator will present the most reliable informations. The success of single cell culture of tubercle bacillus, however, has been ever scarcely reported. In this connection, Hashimoto ${ }^{19}$ ) used the one-step isolation method of streptomycin-resistant mutants for the purpose of selection of the strains developed 
from a single cell, on the assumption that the resistant mutants are occurring spontaneously in the rate of $1: 10^{7}$ to $1: 10^{8}$ and that streptomycin-resistance is independent from virulence. Then, he tested the virulence of fifty-three substrains thus obtained from the parent strain of human type tubercle bacilli H-2. The result was that these substrains were divided into two types different in virulence as follows; the first type shows high virulence against guinea pigs regardless of the infection route, and the second type is quite avirulent against them when injected subcutaneously but virulent if injected intraveneously. In other words, two types of virulence were found in tubercle bacilli in the point of invasiveness from subcutaneous tissue to internal organs through lymphnodes. The cells, which are similar in virulence to H37Ra, however, were not isolated by this method. On the other hand, Steenken ${ }^{20}$ ) was able to obtain avirulent cultures within a relatively short period of time by selecting the secondary growth which developed from the colonies undergoing autolysis. In this manner, R1 and H37Ra strains were dissociated. Although the microbial genetics of the factors responsible for the virulence of tubercle bacilli has not yet advanced, it will be an established fact that the mutations from virulent to avirulent type are taking place in the bacterial population, and that as the result of this the population is heterogeneous concerning virulence. Therefore, if we inject a suspension of tubercle bacilli to experimental animals, it must be kept in mind, as suggested from the fact cited above, that the bacterial cells of different virulence are injected simultaneously. The classical experiment by DeKruif ${ }^{21}$ ) has evidently shown this fact, and the recent report by Miller ${ }^{22}$ ) is also suggestive. Therefore, the situation will be quite similar to that created in the present experiments. Therefore, it will be easily analogized that among the bacterial cells injected avirulent variants disappeared rapidly from the hosts being destroyed by the immune power which is stimulated and enhanced particularly by the proliferation of virulent tubercle bacilli. The discussion made so far will present a suggestion available for the understanding of the mechanism of the virulence-enhancement of tubercle bacilli by animal passage, of which the authors have already described. Last of all, a further discussion will be made of the reason why the more virulent are the bacilli, the more intensely the immunity is produced. In this respect, we should like to think that H37Rv and H37Ra are almost the same in the quality or something like protective antigens capable of stimulating the production of the antibacterial immunity, but the latter strain is lacking in the capacity to multiply in vivo to a degree enough to reach the total amount of the antigens necessary for the production of the potent immunity. The bacterial infection and immunity develops on the basis of the interaction between microorganisms and host cells. Particularly in tuberculosis, the occurrence of allergic state and the formation of special lesions exert many influences on the course of infection and then in turn the allergic state and the Iesions were modified by the altered state of infection. In this way, the patho- 
genesis of tuberculosis presents a very complicated picture. In this paper, the character of tubercle bacilli was principally discussed for the understanding of the problem under consideration.

\section{SUMMARY}

The mechanism of virulence-enhancement of tubercle bacilli by animal passage was studied experimentally in guinea pigs, particularly in reference to an interference phenomenon between virulent and avirulent tubercle bacilli concerning their multiplication and survival in guinea pigs.

1) The virulence of different strains of tubercle bacilli was shown by the growth curve in vivo after the intravenous injection.

2) The more virulent were the bacilli, the more intensely was produced the immunity.

3) When the avirulent bacilli were introduced into guinea pigs with a small dose of the virulent bacilli, the former bacilli disappeared from the hosts more rapidly than in the case of the injection singly with the avirulent bacilli.

4) This phenomenon was explained as follows. The intense immunity produced by the proliferation of the virulent bacilli destroyed more readily the avirulent bacilli in the earlier period of infection. On the contrary, however, when only the avirulent bacilli were introduced, the resulted immunity was weak and so those bacilli could remain in vivo in a relatively longer period of time despite their poor capacity to multiply.

5) From this experiment, the virulence-enhancement phenomenon of tubercle bacilli by animal passage was discussed.

\section{REFERENCES}

1) Dubos, R. J.: The bacterial cell, Harvard University Press, 1945.

2) Pierce, C. H. et al.: Multiplication and survival of tubercle bacilli in the organs of mice. J. Exp. Med., 97, 189-205, 1953.

3) Hashimoto, T. and Sekine, U.: Dissociation of tubercle bacilli of different virulence by the isolation of streptomycin-resistant mutants. Medicine and Biology, 31, 115-119, 1954. (in Japanese)

4) Hashimoto, T.: The virulence of a streptomycin-dependent strain of tubercle bacilli. Medicine and Biology, 23, 201-204, 1952.

5) Suter, E.: Multiplication of tubercle bacilli within mononuclear phagocytes in tissue culture derived from normal animals and animals vaccinated with BCG. J. Exp. Med., 97, 235-245, 1953.

6) Kanai, K. and Yanagisawa, K.: Studies on the reinfection in experimental tuberculosis of guinea pigs. Jap. J. Med. Sci. Biol., 8, 115-127, 1955.

7) MacLeod, C. M. and Pappenheimer, A. M. Jr.: Property of bacteria which enable them to cause disease. Bacterial and Mycotic Infection of Man, Edited by Dubos, R. J., J. B. Lippincott Co., Philadelphia, 1948.

8) See 1)

9) Hadley, P. and Wetzel, V.: Conditions contributing to streptococcal virulence. I. Tntra-phasic contrasted with inter-phasic variation. J. Bact., 45, 529-544, 1943. 
10) Barnett, M., Bushby, S.R.M. and Mitchison, D. A.: Tubercle bacilli resistant to isoniazid:virulence and response to treatment with isoniazid in guinea pigs and mice. Brit. J. Exper. Path., 3.4, 568-581, 1953.

11) Middlebrook, G. and Cohn, M. L.: Some observations on the pathogenicity of isoniazid-resistant variants of tubercle bacilli. Science, 118, 297-299, 1953.

12) Morse, W. C. et al.: Studies of the virulence of isoniazid-resistant tubercle bacilli in guinea pigs and mice. Am. Rev. Tuberc., 69, 464-468, 1954.

13) Karlson, A. G. and Ikemi, Y.: Comparison of the virulence for mice and guinea pigs of an isoniazid-sensitive tubercle bacillus and its isoniazid-resistant variant. Proc. Staff. Meet., Mayo Clin., 29, 119-124, 1954.

14) Saenz, A.: Le probleme de la virulence du bacille de Koch. Rev. de la Tbc., 5, 1030, 1939.

15) Choucroun, N.: Tubercle bacilli antigens. Biological properties of two substances isolated from paraffin oil extract of dead tubercle bacilli. Am. Rev. Tuberc., LVI, 202-226, 1947.

16) Bloch, H.: Studies on the virulence of tubercle bacilli. Isolation and biological properties of a constituent of virulent organisms. J. Exp. Med., 91, 197-217, 1950.

17) Tsumita, T.: Lipids of tubercle bacilli. Biological science, 6, 1-6, 1954.

18) Dubos, R. J.: Cellular structures and functions in parasitism. Bact. Rev. 12, 173-197, 1948.

19) See 3)

20) Steenken, W., Jr.: Spontaneous lysis of tubercle bacilli on artificial media. Am. Rev. Tuberc., 38, 777-790, 1938.

21) De Kruif, P.: Dissociation of microbic species. I. Coexistence of individuals of different degree of virulence in cultures of the Bacillus of Rabbit Septicaemia. J. Exp. Med., 33, 773-789, 1921.

22) Miller, R. Jr.: Studies on the genetics of the Mycobacteria. I. Detection of small numbers of virulent tubercle bacilli when coexisting with attenuated tubercle bacilli in mice. Am. Rev. Tuberc., 70, 1053-1063, 1954. 